\title{
Sintesis Nanopartikel Zink Oksida (ZnO) dengan Penambahan Ekstrak Klorofil dari Daun Suji sebagai sumber Capping Agent
}

\author{
Yunita, Nurlina Nurlina*, Intan Syahbanu \\ Program Studi Kimia, FMIPA, Universitas Tanjungpura, Jl. Prof. Dr. H.Hadari Nawawi, Pontianak \\ *Email : nurlina@chemistry.untan.ac.id \\ (Diterima 03 September 2020; Disetujui 21 November 2020; Dipublikasikan 29 Desember 2020)
}

\begin{abstract}
Abstrak
Zink oksida merupakan oksida logam semikonduktor yang telah banyak diteliti secara luas aplikasinya. Partikel ZnO berukuran mikro hingga nanometer dapat disintesis dengan penambahan capping agent, yaitu senyawa atau ekstrak yang berperan mencegah terjadinya aglomerasi partikel. Pendekatan sintesis hijau (green synthesis) ZnO dalam penelitian ini bertujuan untuk mengetahui pengaruh penambahan klorofil dari daun suji sebagai capping agent dengan variasi konsentrasi terhadap karakteristik (serapan infra merah, ukuran kisi kristal dan energi celah pita) ZnO yang dihasilkan. Sintesis ZnO dilakukan dengan prekursor zink nitrat, penambahan larutan ammonium hidroksida dan klorofil ( $\mathrm{Chl}$ ) dengan konsentrasi bervariasi (Chl 1 = 19,60 $\mu \mathrm{M}$; Chl $2=2,45 \mu \mathrm{M}$ dan Chl $3=0,15 \mu \mathrm{M}$ ). Sintesis dilakukan secara hidrotermal dalam autoclave yang dipanaskan pada temperatur $150^{\circ} \mathrm{C}$ dan $180^{\circ} \mathrm{C}$. Pertumbuhan kristal ZnO terjadi saat proses kalsinasi selama 3 jam pada temperatur $400^{\circ} \mathrm{C}$. Zink oksida hasil sintesis menunjukkan puncak serapan IR pada bilangan gelombang 447,49 $\mathrm{cm}^{-1}$ dan 601,79 $\mathrm{cm}^{-1}$, yang khas untuk vibrasi ulur Zn-O. Difraktogram XRD menunjukkan puncak-puncak kristal ZnO dengan struktur hexagonal wurtzite pada $2 \theta$ sekitar $31^{\circ}, 34^{\circ}$, $36^{\circ}, 47^{\circ}, 56^{\circ}, 62^{\circ}, 68^{\circ}$ dan $89^{\circ}$. Ukuran kristal ZnO terkecil adalah $22,80 \mathrm{~nm}$, yaitu ZnO dengan penambahan Chl 1. Nanopartikel ZnO hasil sintesis dengan penambahan Chl 1 menghasilkan nilai energi celah pita 3,29 eV, sedangkan nilai energi celah pita ZnO kontrol yaitu 3,25 eV. Morfologi permukaan ZnO menunjukkan terjadinya aglomerasi. Berdasarkan penelitian, diperoleh bahwa penambahan Chl 1 dalam sintesis ZnO menghasilkan ZnO nanokristal dengan energi celah pita terbesar.
\end{abstract}

Kata kunci: hidrotermal, klorofil, ZnO

\section{Latar Belakang}

Zink oksida (ZnO) merupakan salah satu jenis semikonduktor tipe-n dari golongan II-VI yang memiliki lebar band gap 3,2 eV pada temperatur ruang [1]. Oksida logam ini memiliki sifat yang ramah lingkungan, tidak beracun dan tahan terhadap korosi. Material ini telah banyak diteliti aktivitasnya sebagai antijamur [2], antibakteri [3], antiinflamasi [4], antimikroba dan antioksidan [5], antikanker [6], tabir surya [7], fotoanode pada sel surya [8]; fotokatalis [9], antikorosi [10] dan sensor gas [11]. Karakteristik dan kinerja ZnO sangat bergantung pada ukuran partikel, bentuk, dan morfologi [12]. Zink oksida dapat disintesis dengan metode sol-gel, hidrotermal, presipitasi dan metode lainnya. Metode sintesis $\mathrm{ZnO}$ secara umum dilakukan dengan metode bottom-up, yaitu metode sintesis partikel secara kimia yang akan menghasilkan partikel dari sejumlah material awal (precursor). Pada penelitian ini, dilakukan sintesis ZnO dengan menggunakan metode hidrotermal. Kelebihan metode hidrotermal adalah meningkat- kan kemurnian, homogenitas yang baik, dan waktu reaksi cepat [13].

Partikel ZnO yang disintesis dapat menghasilkan partikel berukuran mikro hingga nanometer. Tantangan dalam sintesis $\mathrm{ZnO}$ dengan partikel berskala nanometer adalah mencegah terjadinya aglomerasi partikel, yaitu dengan penambahan capping agent. Peran capping agent dalam menstabilkan ZnO dan mencegah aglomerasi partikel dapat dijelaskan melalui berbagai mekanisme, antara lain melalui pembentukan rintangan sterik [14]; mengontrol pertumbuhan partikel dengan cara menurunkan energi permukaan partikel, sehingga agregasi partikel dapat dihindari [15]; berperan sebagai reduktor ion $\mathrm{Zn}(\mathrm{II})$ menjadi atom $\mathrm{Zn}(0)$ [16]; membentuk senyawa koordinasi yang stabil dengan ion logam Zn(II) [17]; dan berperan sebagai katalis yang menghasilkan ion hidroksida atau sebagai pengkhelat dalam pembentukan kompleks [18].

Capping agent yang dapat digunakan dalam sintesis ZnO dapat menggunakan ekstrak tanaman seperti ekstrak daun aloe vera [19] dan antosianin 
dari ekstrak ketan hitam [20]. Capping agent lain yang pernah digunakan antara lain asam sitrat, enzim, senyawa dengan gugus fungsi (alkohol, aldehid, amina, asam karboksilat, keton, dan sulfihidril), peptida, asam tartarat, dan asam tanat [21].

Pada penelitian ini sintesis $\mathrm{ZnO}$ akan dilakukan dengan menggunakan ekstrak klorofil. Klorofil diduga dapat dijadikan sebagai capping agent karena mengandung gugus karbonil $(\mathrm{C}=0)$ dan ester (-COO-). Gugus-gugus ini diharapkan dapat berinteraksi dengan ion $\mathrm{Zn}$ (II) sehingga tidak terjadi aglomerasi dan membentuk $\mathrm{ZnO}$ yang stabil. Selain itu klorofil dapat dengan mudah diesktraksi dari beragam jenis tumbuhan hijau. Klorofil yang digunakan dalam penelitian ini diekstraksi dari daun suji, kemudian digunakan untuk sintesis ZnO. Penelitian mengenai pengaruh penambahan klorofil pada sintesis $\mathrm{ZnO}$ belum banyak ditemukan publikasinya, sehingga membuka peluang penelusuran keanekaragaman struktur morfologi dan karakteristik $\mathrm{ZnO}$ yang disintesis dengan penambahan klorofil.

\section{Metodologi}

\section{A. Preparasi Daun Suji}

Daun suji dibersihkan terlebih dahulu dengan air keran mengalir, kemudian dikeringanginkan. Setelah kering, daunnya dipotong kecil-kecil.

\section{B. Ekstraksi Klorofil dari Daun Suji}

Daun suji yang telah dipotong kecil-kecil ditambahkan dengan aseton $80 \%$, kemudian dikocok dengan magnetic stirrer selama 24 jam menghasilkan esktrak klorofil [20]. Ekstrak disaring dan diambil filtratnya. Filtrat dipartisi menggunakan corong pisah dengan pelarut $n$ heksana hingga diperoleh dua lapisan yang terpisah. Lapisan atas diambil dan dipekatkan dengan rotary evaporator [22].

\section{C. KLT klorofil dari Daun Suji}

Ekstrak yang telah dipekatkan, dilarutkan dengan aseton. Selanjutnya ditotolkan pada plat KLT preparatif dengan perbandingan pelarut aseton dan n-heksana (3:7). Diukur nilai Rf dari masing-masing noda yang dihasilkan [23].

\section{D. Pembuatan Larutan Klorofil dengan Variasi Konsentrasi}

Noda yang menunjukkan nilai Rf klorofil dikerok dan dilarutkan dengan aseton $8 \mathrm{~mL}$, kemudian disaring. Larutan tersebut diukur absorbansinya dengan instrumen Uv-Vis pada panjang gelombang 200-800nm. Hasil scanning larutan klorofil diperoleh spektrum klorofil yang memiliki puncak pada panjang gelombang $410 \mathrm{~nm}$ dan $664 \mathrm{~nm}$. Hasil ini sesuai dengan klorofil standar [24], sehingga untuk pengukuran konsentrasi klorofil digunakan nilai absorptivitas molar klorofil standar ini. Konsentrasi larutan ditentukan berdasarkan persamaan Hukum Lambert-Beer (Persamaan 1), dimana $\varepsilon$ merupakan absorptivitas molar klorofil berdasarkan referensi klorofil standar yaitu 78,75 x $10^{3} \mathrm{Lmol}^{-1} \mathrm{~cm}^{-1}$, absorpsi (A) diperoleh dari hasil pengukuran, sehingga diperoleh nilai konsentrasi (c).

Berdasarkan perhitungan dengan persamaan Lambert-Beer:

$$
A=\varepsilon b c
$$

dengan, A adalah absorbansi larutan; $\varepsilon$ adalah absorptivitas molar larutan, $\mathrm{b}$ adalah ketebalan sel dan c merujuk pada konsentrasi larutan, konsentrasi larutan klorofil yang diukur adalah 2,45 $\mu \mathrm{M}$ (selanjutnya disebut Chl 2). Konsentrasi ini dijadikan dasar untuk perhitungan konsentrasi klorofil (1mL), dimana konsentrasinya adalah 19,60 $\mu \mathrm{M}$ (selanjutnya disebut Chl 1). Larutan ini merupakan larutan stok. Selanjutnya dari larutan klorofil dengan konsentrasi 2,45 $\mu \mathrm{M}$ dipipet $1 \mathrm{~mL}$ dan diencerkan menjadi $16 \mathrm{~mL}$, diperoleh konsentrasi larutan adalah $0,15 \mu \mathrm{M}$ (selanjutnya disebut $\mathrm{Chl}$ 3). Ketiga larutan klorofil dengan konsentrasi berbeda tersebut (Chl 1, Chl 2 dan Chl 3) ditambahkan pada larutan zink nitrat.

\section{E. Sintesis ZnO dengan Klorofil dari Ekstrak Daun Suji dengan Metode Hidrotermal}

Sintesis nanopartikel $\mathrm{ZnO}$ dengan ekstrak klorofil dari daun suji menggunakan metode hidrotermal [25]. Sebanyak 1,36 g Zn( $\left(\mathrm{NO}_{3}\right)_{2} \cdot 4 \mathrm{H}_{2} \mathrm{O}$ dilarutkan dalam $100 \mathrm{~mL} \mathrm{H}_{2} \mathrm{O}$. Larutan tersebut ditambahkan ekstrak klorofil daun suji setetes demi tetes dengan variasi konsentrasi ( $\mathrm{Chl} \mathrm{1,} \mathrm{Chl} 2$ dan Chl 3). Larutan $\mathrm{NH}_{4} \mathrm{OH}$ ditambahkan setetes demi tetes ke dalam larutan $\mathrm{Zn}\left(\mathrm{NO}_{3}\right)_{2}$ yang telah ditambahkan klorofil hingga larutan mencapai $\mathrm{pH}$ 7, disertai dengan pengadukan konstan selama 1 jam.

Campuran ini dipindahkan ke wadah reaktor autoclave teflon-lined stainless steel untuk dilakukan proses hidrotermal. Autoclave yang telah 
berisi campuran dipanaskan dengan temperatur $150^{\circ} \mathrm{C}$ selama $3 \mathrm{jam}$. Setelah $3 \mathrm{jam}$, autoclave dibiarkan hingga suhunya sama dengan suhu ruang.

Reaksi yang berlangsung di dalam autoclave menghasilkan filtrat dan endapan. Endapan yang terbentuk dibilas dengan akuades dan etanol. Endapan dikeringkan pada temperatur $60^{\circ} \mathrm{C}$. Endapan kemudian dikalsinasi pada temperatur $400^{\circ} \mathrm{C}$, selama $3 \mathrm{jam}$. Setelah proses kalsinasi, diperoleh serbuk putih. Sintesis ZnO diulang prosedurnya tanpa penambahan klorofil dan tanpa perlakuan hidrotermal yang digunakan sebagai kontrol.

\section{F. Karakterisasi $\mathrm{ZnO}$ dan $\mathrm{Zn}\left(\mathrm{NO}_{3}\right)_{2 .} \cdot 4 \mathrm{H}_{2} \mathrm{O}$}

Nanopartikel $\mathrm{ZnO}$ yang dihasilkan dikarakterisasi dengan beberapa instrumen, seperti Fourier Transform Infra Red Spectroscopy (FTIR), X-Ray Diffraction (XRD), Diffused Reflectance UV (DR-UV) dan Scanning Electron Microscope with Energy Dispersive X-ray Spectroscopy (SEM-EDX). Analisis dengan FTIR digunakan untuk mengidentifikasi gugus fungsi $\mathrm{ZnO}$. Kristalinitas ZnO dan ukuran kisi kristal ZnO dianalisis dengan instrumen XRD. Ukuran kisi kristal dapat dihitung dengan persamaan DeybeScherrer :

$$
D=\frac{0,9 \lambda}{B \cos \theta}
$$

dengan $\mathrm{D}$ adalah ukuran kisi kristal (nm); $\lambda$ adalah panjang gelombang $(\mathrm{nm})$; $\mathrm{B}$ adalah diameter nanopartikel kisi kristal (FWHM) dan $\theta$ adalah sudut Bragg $\left({ }^{\circ}\right)$. Analisis dengan instrumen hasil spektra pengukuran dengan menggunakan DR-UV dapat digunakan untuk menghitung energi band gap nanopartikel ZnO. Instrumen SEM-EDX digunakan untuk melihat morfologi permukaan dan komposisi unsur permukaan nanopartikel $\mathrm{ZnO}$ yang dihasilkan.

Prekursor $\mathrm{Zn}\left(\mathrm{NO}_{3}\right)_{2} .4 \mathrm{H}_{2} \mathrm{O}$ dikarakterisasi dengan menggunakan analisis $X$-Ray Fluorescence (XRF). Analisis ini berguna untuk mengetahui komposisi dari prekursor yang digunakan beserta konsentrasi unsur-unsur yang terkandung dalam prekursor tersebut.

\section{Hasil dan Pembahasan}

\section{A. Sintesis ZnO}

Proses pembentukkan $\mathrm{ZnO}$ diawali dengan pembuatan larutan zink nitrat. Dalam larutan, zink nitrat akan terionisasi menjadi ion $\mathrm{Zn}(\mathrm{II})$ dan ion nitrat. Ekstrak klorofil ditambahkan ke dalam larutan zink nitrat. Campuran tersebut kemudian ditambahkan larutan $\mathrm{NH}_{4} \mathrm{OH}$ untuk membentuk hidroksida logam dan berperan untuk mengikat kluster ion $\mathrm{Zn}^{2+}$ sehingga permukaan partikel diselimuti oleh ion-ion yang bermuatan negatif yang mengakibatkan adanya gaya tolak-menolak antar muatan sejenis sehingga dapat mencegah terjadinya agregasi antar partikel [26]. Ion Zn(II) bereaksi dengan ion hidroksida dari $\mathrm{NH}_{4} \mathrm{OH}$ membentuk larutan keruh yang berubah menjadi koloid berwarna putih. Dalam larutan, ion Zn(II) yang memiliki bilangan koordinasi 4 dapat mengikat empat molekul air membentuk kompleks tetrahydroxozincate.

Setelah proses hidrotermal, diperoleh endapan putih $\mathrm{Zn}(\mathrm{OH})_{2}$. Endapan $\mathrm{Zn}(\mathrm{OH})_{2}$ akan menghasilkan padatan $\mathrm{ZnO}$ selama proses kalsinasi. Kalsinasi yang dilakukan pada temperatur $400^{\circ} \mathrm{C}$. Berdasarkan penelitian Kumaresan et al. (2017) dan Septiani et al. (2017), bahwa temperatur kalsinasi $400{ }^{\circ} \mathrm{C}$ dapat membentuk partikel ZnO [25][20]. Berikut ini adalah mekanisme reaksi yang terjadi dalam proses sintesis $\mathrm{ZnO}$ [27]:

$$
\begin{gathered}
\mathrm{Zn}\left(\mathrm{NO}_{3}\right)_{(a q)}^{2} \rightarrow \mathrm{Zn}_{(a q)}^{2+}+2 \mathrm{NO}_{3(a q)}^{-} \\
\mathrm{Zn}_{(a q)}^{2+}+2 \mathrm{OH}_{(a q)}^{-} \rightarrow \mathrm{Zn}(\mathrm{OH})_{2(\mathrm{~s})} \\
\mathrm{Zn}(\mathrm{OH})_{2(s)}+2 \mathrm{OH}_{(a q)}^{-} \rightarrow\left[\mathrm{Zn}(\mathrm{OH})_{4}\right]_{(a q)}^{2-} \\
\mathrm{Zn}(\mathrm{OH})_{2(\mathrm{~s})} \rightarrow \mathrm{ZnO}_{(\mathrm{s})}+\mathrm{H}_{2} \mathrm{O}
\end{gathered}
$$

\section{B. Karakterisasi Fourier Transform Infra Red Spectroscopy (FTIR)}

Karakterisasi bubuk putih ZnO dengan FTIR bertujuan untuk mengetahui gugus-gugus fungsi yang terdapat dalam sampel. Spektra FTIR ini

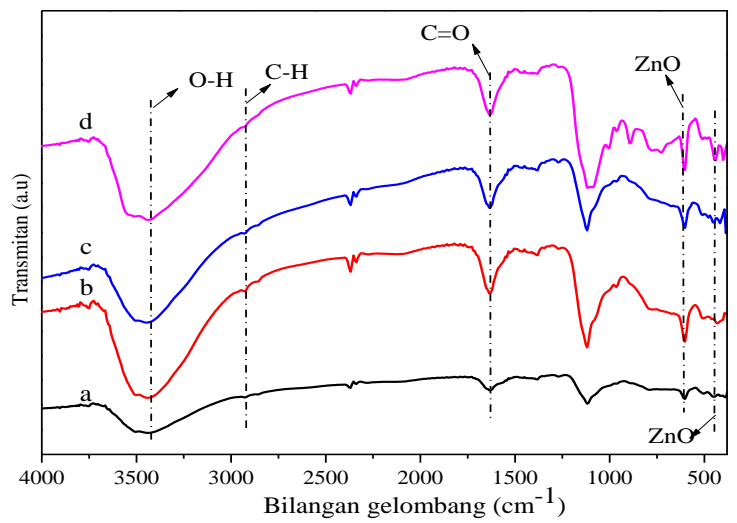

Gambar 1. Spektra FTIR (a) nanopartikel ZnO kontrol, (b) Chl 1, (c) Chl 2, (d) Chl 3. 

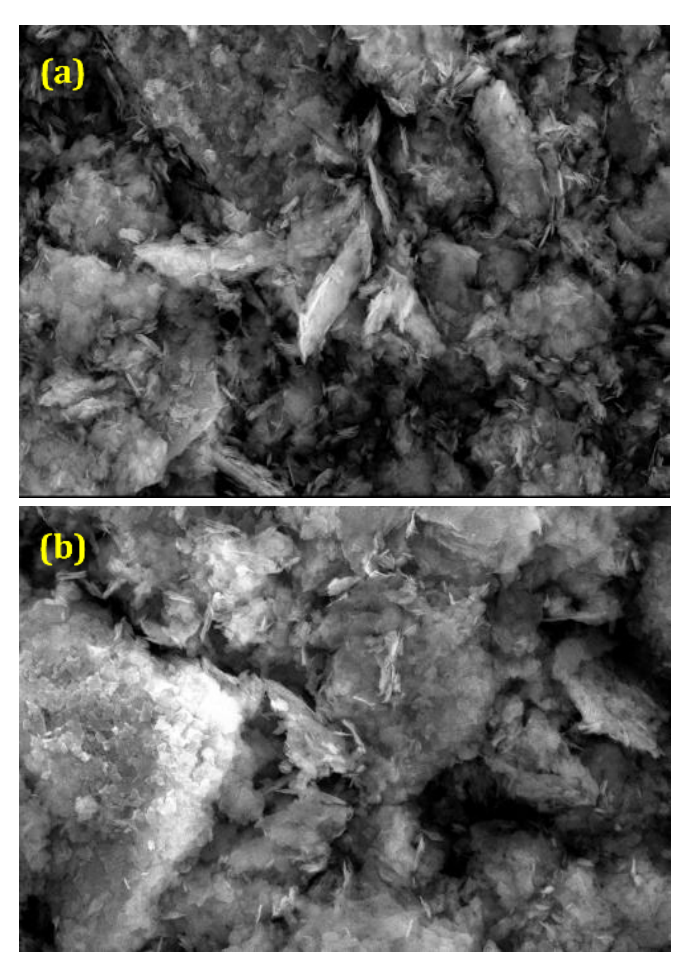

Gambar 2. Hasil SEM (a) ZnO kontrol dan (b) ZnO dengan penambahan $\mathrm{Chl} 1$.

diukur dari kisaran $400-4000 \mathrm{~cm}^{-1}$ yang ditunjukkan dalam Gambar 1.

Berdasarkan Gambar 1, bilangan gelombang dengan pita lebar antara $3200-3600 \mathrm{~cm}^{-1}$ berpusat pada $3441,01 \mathrm{~cm}^{-1}$ dan $3448,72 \mathrm{~cm}^{-1}$, disebabkan karena getaran peregangan ikatan kimia dari gugus $-\mathrm{OH}$ yang dapat berasal dari molekul air yang diabsorp oleh $\mathrm{ZnO}$ atau dapat menunjukkan adanya pembentukan ikatan hidrogen [28]. Puncak pada daerah 1635,64 $\mathrm{cm}^{-1}$ menunjukkan vibrasi tekuk $-\mathrm{OH}$, mungkin disebabkan adanya permukaan $\mathrm{ZnO}$ yang masih menempel molekul air [29]. Puncak $\mathrm{ZnO}$ muncul pada bilangan gelombang 447,48$486,06 \mathrm{~cm}^{-1}$ dan $601,79 \mathrm{~cm}^{-1}$. Hasil FTIR sesuai dengan hasil analisis XRD yang menunjukkan adanya puncak $\mathrm{ZnO}$.

\section{C. Karakterisasi Zno dengan Scanning Electron Microscope with Energy Dispersive $X$ - Ray Spectroscopy (SEM-EDX)}

Karakterisasi SEM-EDX bertujuan untuk mengetahui bentuk morfologi permukaan nanopartikel ZnO. Gambar 2, menunjukkan citra dari morfologi $\mathrm{ZnO}$ kontrol dan $\mathrm{ZnO}$ dengan penambahan Chl 1. Hasil pencitraan SEM menggambarkan $\mathrm{ZnO}$ yang diperoleh mengalami aglomerasi sehingga bentuknya tidak dapat diprediksi karena celah antar nanopartikel tidak terlihat jelas. Aglomerasi ini menyebabkan ter- bentuknya ukuran yang lebih besar. Dari hasil SEM ini dapat disimpulkan bahwa bentuknya tidak homogen. Hal ini dikarenakan koloid $\mathrm{ZnO}$ mudah terjadi aglomerasi kembali sehingga ukuran nanopartikel menjadi lebih besar dan tidak stabil.

Analisis persentase unsur dalam sampel dilakukan menggunakan instrumen EDX. Hasil analisis EDX pada ZnO kontrol yaitu mengandung unsur C (28,64\%), O (18,04\%), Si (0,36\%), S (3,72\%), Cu (1,84\%) dan Zn (47,41\%). Sedangkan hasil analisis EDX pada $\mathrm{ZnO}$ dengan penambahan Chl 1 mengandung unsur C (15,73\%), $\mathrm{O}(22,00 \%)$, S (5,39\%), Cu (2,06\%), Zn (54,83\%). Hasil ini menunjukkan bahwa $\mathrm{ZnO}$ kontrol maupun dengan penambahan klorofil terdapat unsur-unsur lainnya dengan \%massa yang kecil.

\section{D. Karakterisasi $X$ - Ray Diffraction (XRD)}

Hasil analisis XRD pada Gambar 3, menunjukkan puncak-puncak difraktogram $\mathrm{ZnO}$ yang disintesis dengan variasi konsentrasi klorofil dan tanpa klorofil. Gambar 3 (a) menghasilkan puncak ZnO yang berada di sudut $2 \theta$ dengan indeks Miller yaitu $31,86^{\circ}(100), 34,43^{\circ}(002), 36,36^{\circ}$ (101), $47,62^{\circ}$

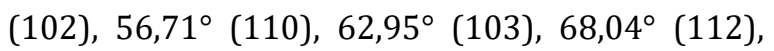
$68,77^{\circ}(201)$, dan $89,71^{\circ}(203)$, yang telah disesuaikan dengan International Centre for Diffraction Data (ICDD) NO. 01-078-3315. Puncak dengan masing-masing $2 \theta$ tersebut sesuai dengan difraktogram $\mathrm{ZnO}$ peneliti sebelumnya [30]. Selain puncak $\mathrm{ZnO}$, puncak lain juga ditemukan dengan intensitas tinggi pada sudut $2 \theta$ yaitu $12,19^{\circ}, 21,38^{\circ}$, $24,61^{\circ}, 32,86^{\circ}, 35,12^{\circ}$, dan $58,60^{\circ}$.

Gambar 3 (b) menghasilkan puncak ZnO yang berada di sudut $2 \theta$ dengan indeks Miller yaitu $36,32^{\circ}(101), 56,74^{\circ}(110)$, dan $68,77^{\circ}(112)$, sesuai dengan data ICDD NO. 01-078-3315. Pola difraksi $\mathrm{ZnO}$ dengan penambahan Chl 1 menghasilkan puncak yang lebih sedikit dari pola difraksi $\mathrm{ZnO}$

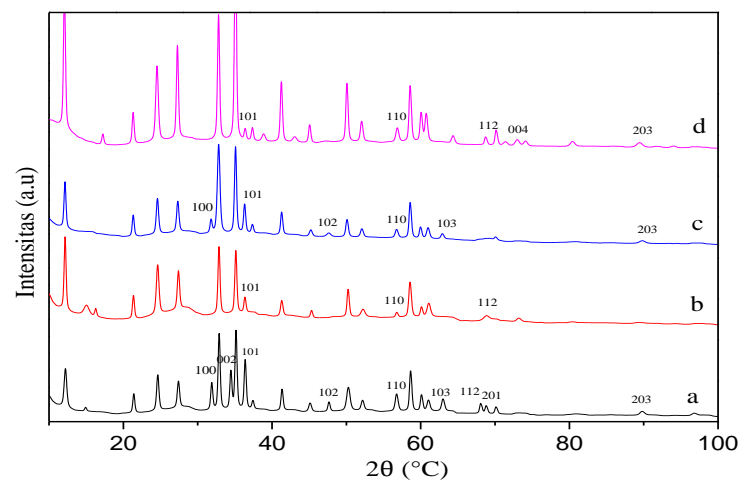

Gambar 3. Pola difraksi XRD (a) ZnO kontrol, (b) Chl 1, (c) Chl 2, (d) Chl 3. 
kontrol. Puncak lain juga ditemukan dengan intensitas tinggi pada sudut $2 \theta$ yaitu $12,15^{\circ}, 21,34^{\circ}$, $24,59^{\circ}, 32,84^{\circ}, 35,10^{\circ}, 50,20^{\circ}$ dan $58,52^{\circ}$.

Gambar 3 (c) menghasilkan puncak $\mathrm{ZnO}$ yang berada di sudut $2 \theta$ dengan indeks Miller yaitu $31,77^{\circ}$ (100), $36,28^{\circ}$ (101), 47,59 ${ }^{\circ}$ (102), 56,71 ${ }^{\circ}$ (110), $62,86^{\circ}(103)$ dan $89,72^{\circ}$ (203), yang telah disesuaikan dengan data ICDD NO. 01-078-3315. Puncak lain juga ditemukan dengan intensitas tinggi pada sudut $2 \theta$ yaitu $12,13^{\circ}, 21,31^{\circ}, 24,56^{\circ}$, $27,29^{\circ}, 32,79^{\circ}, 35,06^{\circ}, 50,05^{\circ}$ dan $58,54^{\circ}$.

Gambar 3 (d) menghasilkan puncak ZnO yang berada di sudut $2 \theta$ dengan indeks Miller yaitu $36,36^{\circ}$ (101), $56,80^{\circ}$ (110), 68,69 ${ }^{\circ}$ (112), 72,92 (004) dan $89,36^{\circ}$ (203), yang telah disesuaikan dengan data ICDD NO. 01-078-3315. Puncak lain juga ditemukan dengan intensitas tinggi pada sudut $2 \theta$ yaitu $12,07^{\circ}, 21,29^{\circ}, 24,50^{\circ}, 27,25^{\circ}, 32,78^{\circ}$, $35,05^{\circ}, 41,22^{\circ}, 50,04^{\circ}$ dan $58,54^{\circ}$.

Gambar 3 (a-d) menghasilkan puncak-puncak yang merupakan karakteristik dari ZnO dengan struktur hexagonal wurtzite. Pola difraksi menunjukkan munculnya puncak ZnO dan puncak lain dengan intensitas yang tinggi. Sesuai dengan analisis SEM-EDX ternyata pada ZnO hasil sintesis ditemukan beberapa kandungan unsur lain selain Zn dan O, yaitu C, Si, S dan Cu. Sehingga, puncak dengan intensitas yang tinggi diperkirakan merupakan puncak $\mathrm{SiO}_{2}, \mathrm{~S}, \mathrm{Si}, \mathrm{Zn}(\mathrm{OH})_{2}$, dan $\mathrm{Cu}$. Puncak SiO2 memiliki $2 \theta$ sebesar 21,29-21,38 [31], puncak S memiliki $2 \theta$ sebesar 24,50-24,61 [32], puncak Si memiliki $2 \theta$ sebesar 27,25-27,39 [33], puncak $\mathrm{Zn}(\mathrm{OH})_{2}$ memiliki $2 \theta$ sebesar 32,78-32,86 dan 35,05-35,12 [34], dan puncak $\mathrm{Cu}$ memiliki $2 \theta$ sebesar 41,22-41,31 [35] dan 50,04-50,23 [36].

Adanya puncak selain ZnO, menunjukkan bahwa ZnO yang dihasilkan dalam penelitian ini memiliki kemurnian yang relatif rendah, karena terdapat puncak lain dengan intensitas yang tinggi. Berdasarkan hasil uji XRF terhadap prekursor $\mathrm{Zn}\left(\mathrm{NO}_{3}\right)_{2} .4 \mathrm{H}_{2} \mathrm{O}$, diketahui prekursor mengandung 79,70\% Zn, 9\% S, 0,088\% Cu, 0,17\% Ca, 0,052\% Cr, 0,12\% Fe, 0,085\% Ni, 2,8\% Zr, 7,6\% Mo, 0,07\% Er dan $0,3 \% \mathrm{Yb}$, sehingga diduga bahwa prekursor terkontaminasi.

Berdasarkan pola difraksi yang dihasilkan maka dapat dilakukan perhitungan melalui persamaan Debye-Scherrer (Persamaan 2) untuk memperkirakan ukuran kisi kristal ZnO berdasarkan puncak dengan intensitas tertinggi. Perhitungan ukuran nanopartikel dengan pendekatan persamaan Debye-Scherrer memberikan deskripsi ukuran nanopartikel yang bertanggung jawab pada difraksi sinar X.

Analisis XRD pada ZnO kontrol, ZnO dengan penambahan Chl 1, Chl 2, dan Chl 3 masing-masing menghasilkan ukuran kisi kristal berturut-turut sebesar 27,08 nm; 22,80 nm; 25,40 nm; dan 26,88 nm. Ukuran kisi kristal ZnO yang terbentuk pada penelitian ini berukuran nanometer. Ukuran kisi kristal dengan penambahan klorofil berkonsentrasi tinggi lebih kecil daripada kontrol. Hal ini menunjukkan klorofil dapat berperan sebagai capping agent pada sintesis ZnO. Ukuran kisi kristal ZnO terkecil dengan penambahan Chl 1 yaitu 22,80nm. Semakin tinggi konsentrasi klorofil yang ditambahkan mampu menghasilkan ukuran kristal yang semakin kecil.

Berdasarkan nilai FWHM yang diperoleh pada indeks Miller (101) pada keempat sampel memiliki nilai yang sama yaitu $0,3070^{\circ}$. Nilai FWHM dipengaruhi oleh intensitas masing-masing bidang kristal, dimana semakin tinggi intensitas maka nilai FWHM semakin kecil [37]. Pola difraksi Gambar 3 menghasilkan puncak yang cenderung meruncing tajam yang menunjukkan kristalinitas yang tinggi.

\section{E. Karakterisasi Diffused Reflectance UV (DR- UV)}

Karakterisasi DR-UV bertujuan untuk mengetahui besarnya energi celah pita ZnO. Besarnya energi celah pita yang dihasilkan akan mempengaruhi kinerja dari material ZnO dalam mengeksitasi elektron dari pita valensi ke pita konduksi dan berkaitan dengan pengaplikasian ZnO sebagai semikonduktor. Karakterisasi DR-UV pada ZnO kontrol, ZnO dengan penambahan Chl 1, Chl 2, dan Chl 3 masing-masing menghasilkan energi celah pita sebesar 3,25 eV; 3,29 eV; 3,26 eV; dan $3,25 \mathrm{eV}$.

Nanopartikel ZnO yang disintesis dengan penambahan klorofil Chl 1 yang memiliki energi celah pita tertinggi. Energi celah pita ZnO hasil penelitian berada pada rentang nilai 3,25-3,29 eV. Energi celah pita $\mathrm{ZnO}$ berada pada nilai 3,2 eV [1]. Energi celah pita ZnO yang disintesis dengan penambahan klorofil Chl 1, Chl 2 dan Chl 3 sedikit lebih besar daripada energi celah pita $\mathrm{ZnO}$ teoritis. Hasil ini sesuai dengan teori yang menyatakan bahwa semakin kecil ukuran nanopartikel, maka energi celah pitanya akan semakin besar [38]. Penelitian lain juga ada yang menghasilkan pe- 

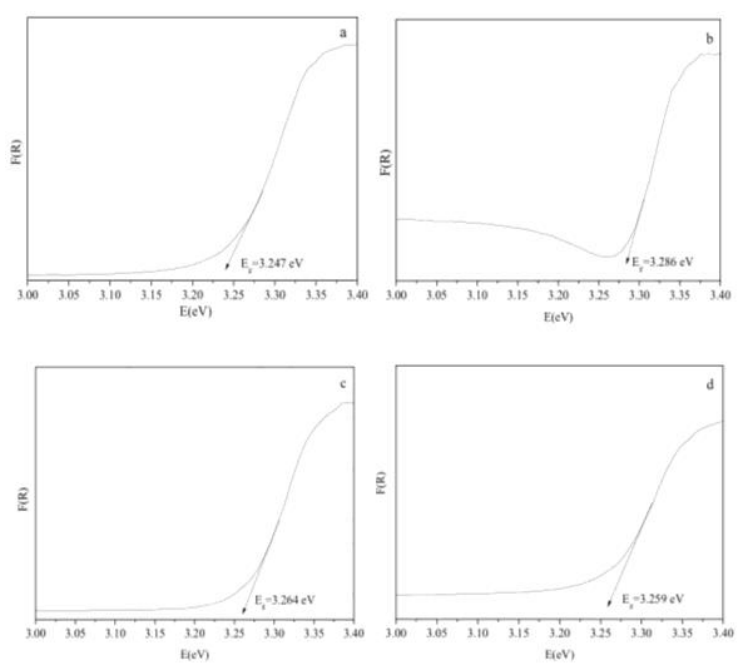

Gambar 4. Energi celah (a) pita kontrol, (b) Chl 1, (c) Chl 2, (d) Chl 3.

ningkatan celah pita dari 3,87 eV (bulk ZnO) menjadi 4,09 eV (nanopartikel ZnO) [29].

Hasil analisis DR-UV sesuai dengan analisis XRD yang menunjukkan terbentuknya ZnO dengan ukuran kisi kristal nanometer yang didukung dengan hasil analisis FTIR yang menunjukkan serapan dari Zn-O.

\section{Kesimpulan}

Zink Oksida (ZnO) berhasil disintesis menggunakan metode hidrotermal dengan pemanasan pada temperatur $150^{\circ} \mathrm{C}$. Zink oksida hasil sintesis menunjukkan serapan pada bilangan gelombang sekitar $601,79 \mathrm{~cm}^{-1}$ dan 447,49 $\mathrm{cm}^{-1}$ yang khas untuk serapan Zn-0. Difraktogram XRD menunjukkan puncak-puncak ZnO pada $2 \theta$ sekitar $31^{\circ}, 34^{\circ}, 36^{\circ}, 47^{\circ}, 56^{\circ}, 62^{\circ}, 68^{\circ}$ dan $89^{\circ}$ yang sesuai dengan ICDD ZnO dengan struktur hexagonal wurtzite. Zink oksida dengan penambahan Chl 1 menghasilkan ukuran kisi kristal paling kecil yaitu 22,80 nm dibandingkan dengan penambahan Chl 2 dan Chl 3 yang menghasilkan ukuran kisi kristal masing-masing sebesar 25,40 nm dan 26,88 nm. Hasil karakterisasi ini menunjukkan bahwa penambahan Chl dengan variasi konsentrasi pada ZnO memberikan pengaruh yang cukup signifikan pada ukuran kristal ZnO. Nanopartikel ZnO hasil sintesis dengan penambahan Chl 1 menunjukkan peningkatan energi celah pita tertinggi yaitu 3,29 eV. Namun, hasil dari morfologi ZnO yang ditambahkan dengan ekstrak klorofil masih mengalami aglomerasi sehingga bentuknya sukar untuk diprediksi.

\section{Daftar Pustaka}

[1] Bessegato, G. G., Guaraldo, T. T., Brito, J. F. De, Brugnera, M. F. and Zanoni, M. V. B., Achievements and Trends in Photoelectrocatalysis: from Environmental to Energy Applications, Electrocatalysis, 6(5), pp. 415-441, 2015.

[2] Sun, Q., Li, J., and Le, T., Zinc Oxide Nanoparticle as a Novel Class of Antifungal Agents: Current Advances and Future Perspectives, Journal of Agricultural and Food Chemistry, 66 (43), pp. 11209-11220, 2018.

[3] Dadi,R., Azounani, R., Traore, M., Mielcarek, C., and Kanaev, A., Antibacterial Activity of $\mathrm{ZnO}$ and $\mathrm{CuO}$ Nanoparticles Against Gram Positive and Gram Negative Strains, Materials Science and Engineering: C, 109968, pp. 1-9, 2019.

[4] Agarwal, H., and Shanmugam, V., A Review on Anti-inflammatory Activity of Green Synthesized Zinc Oxide Nanoparticle: Mechanism-based Approach. Bioorg Chem, 94, 2020.

[5] Safawo, T., Sandeep, B., Pola, S., and Tadesse, A., Synthesis and Characterization of Zinc Oxide Nanoparticles Using Tuber Extract of Anchote (Coccinia abyssinica (Lam.) Cong.) for Antimicrobial and Antioxidant Activity Assessment, OpenNano, 3, pp. 56-63, 2018.

[6] Bisht, G., and Rayamajhi, S., ZnO Nanoparticles: A Promising Anticancer Agent. Nanobiomedicine, 3 (9), pp. 1-11, 2016.

[7] Lu, P. J., Fang, S. W., Cheng, W. L., Huang, S. C., Huang, M. C., and Cheng, H. F., Characterization of Titanium Dioxide and Zinc Oxide Nanoparticles in Sunscreen Powder by Comparing Different Measurement Methods, Journal of Food and Drug Analysis, 26(3), pp. 1192-1200, 2018.

[8] Kumar, R., Umar, A., Kumar, G., Nalwa, H. S., Kumar, A., and Akhtar, M. S., Zinc Oxide Nanostructure-Based Dye-Sensitized Solar Cells, Journal of Materials Science, 52(9), pp. 4743-4795, 2017.

[9] Khalafi, T., Buazar, F., and Ghanemi, K., Phycosynthesis and Enhanced Photocatalytic Activity of Zinc Oxide Nanoparticles Toward Organosulfur Pollutants, Scientific Reports, 9(1), pp. 1-10, 2019.

[10] Setiawan, A., Sintesis dan Karakterisasi ZnO sebagai Coating Antikorosi $\mathrm{ZnO} / \mathrm{Al}(\mathrm{OH})_{3}$ pada Material Baja Karbon, Jurnal Teknik, 39(1), pp. 55-61, 2018.

[11] Riwanda, R. dan Elvaswer, Karakteristik ArusTegangan Komposit dari Bahan Semikonduktor $\mathrm{ZnO}-\mathrm{TiO}_{2}$ Sebagai Sensor Gas Hidrogen, Jurnal Fisika Unand, 6(3), pp. 211216, 2017. 
[12] Mirzaei, H. and Darroudi, M., Zinc Oxide Nanoparticles: Biological Synthesis and Biomedical Applications, Ceramics International, 43(1), pp. 907-914, 2017.

[13] Byrappa, K. and Adschiri, T., Hydrothermal technology for nanotechnology, Progress in Crystal Growth and Characterization of Materials, 53(2), pp. 117-166, 2007.

[14] Javed, R., Usman, M., Tabassum, S., and Zia, M., Effect of Capping Agents: Structural, Optical and Biological Properties of $\mathrm{ZnO}$ Nanoparticles, Applied Surface Science, 386, pp.319-326, 2016.

[15] Phan, C. M. and Nguyen, H. M., Role of Capping Agent in Wet Synthesis of Nanoparticles, The Journal of Physycal Chemistry, 121(17), pp. 3212-3219, 2017.

[16] Khalafi, T., Buazar, F. and Ghanemi, K., Phycosynthesis and Enhanced Photocatalytic Activity of Zinc Oxide Nanoparticles Toward Organosulfur Pollutants, Scientific Reports, 9(6866), pp. 1-10, 2019.

[17] Nava, O. J., Luque, P. A., Gutierrez, C. M. G., Nestor, A. R. V, Beltran, A. C., Gonzalez, M. L. M. and Olivas, A., Influence of Camellia sinensis Extract on Zinc Oxide Nanoparticle Green Synthesis, Journal of Molecular Structure, 1134, pp. 121-125, 2017.

[18] Yuliarto, B., Septiani, N. L. W., Kaneti, Y. V., Iqbal, M., Gumilar, G., Kim, M., Na, J., Wu, K. C.W. and Yamauchi, Y., Green Synthesis of Metal Oxide Nanostructure using Naturally Occurring Compounds for Energy and Environmental Applications, New Journal of Chemistry, 43(40), pp. 15846-15856, 2019.

[19] Ali, K., Dwivedi, S., Azam, A., Saquib, Q., Al-said, M. S., Alkhedhairy, A. A. and Musarrat, J., Aloe vera Extract Functionalized Zinc Oxide Nanoparticles As Nanoantibiotics Against Multi-drug Resistant Clinical Bacterial Isolates, Journal of Colloid and Interface Science, 472, pp. 145-156, 2016.

[20] Septiani, N. I. W., Yuliarto, B., Iqbal, M. and Nugraha, Synthesis of Zinc Oxide Nanoparticles using Anthocyanin as a Capping Agent Synthesis of Zinc Oxide Nanoparticles using Anthocyanin as a Capping Agent, IOP Conference Series: Materials Science and Engineering, 202(1), pp. 1-4, 2017.

[21] Akhtar, M. S., Panwar, J. and Yun, Y., Biogenic Synthesis of Metallic Nanoparticles by Plant Extracts, ACS Sustainable Chemistry and Engineering, 1(6), pp. 591-602, 2013.

[22] Christiana, R., Kristopo, H. and Limantara, L., Photodegradation and Antioxidant Activity of Chlorophyll a From Spirulina (Spirulina sp.) Powder, Indo. J. Chem, 8(2), pp. 236-241, 2008.
[23] Sjursnes, B. J., Kvittingen, L. and Schmid, R., Normal and Reversed-Phase Thin Layer Chromatography of Green Leaf Extracts, Journal of Chemical Education, 92(1), pp. 193196, 2014.

[24] Jabbari, E., Kim, D.H., Lee, L. P., Ghaemmaghami, A. and Khademhosseini, A., Handbook of Biomimetics and Bioinspiration, World Scientific Publishing Co.Pte. Ltd, Singapore, 2014.

[25] Kumaresan, N., Ramamurthi, K., Babu, R. R., Sethuraman, K. and Babu, S. M., Hydrothermally Grown ZnO Nanoparticles for Effective Photocatalytic activity, Applied Surface Science, 418, pp. 138-146, 2017.

[26] Tournebize, J., Boudier, A., Joubert, O., Eidi, H., Bartosz, G., Maincent, P., Leroy, P. and Sapinminet, A., Impact of gold nanoparticle coating on redox homeostasis, International Journal of Pharmaceutics, 438(1-2), pp. 107-116, 2012.

[27] Semenova, A. A., Lashkova, N. A., Maximov, A. I. and Moshnikov, V. A., Formation of Onedimensional ZnO Structures on Flexible Substrates, Journal of Physics: Conference Series, 816, pp. 1-4., 2017.

[28] Geetha, A. and Mallika, J., Synthesis and Characterization of $\mathrm{ZnO}$ Nanoparticles, A Journal of Science and Technology, 3(2), pp. 72-76, 2015.

[29] Osuntokun, J., Onwudiwe, D. C. and Ebenso, E. E., Green Synthesis of ZnO Nanoparticles using Aqueous Brassica oleracea L. var. italica and The Photocatalytic Activity, Green Chemistry Letters and Reviews, 12(4), pp. 444-457, 2019.

[30] Manoj, V., Karthika, M., Kumar, V. S. R. P., Boomadevi, S., Jeyadheepan, K., Karn, R. K., Balaguru, R. J. B., and Pandiyan, S., Synthesis of ZnO Nanoparticles using Carboxymethyl Cellulose Hydrogel, Asian Journal of Applied Sciences, 7(8), pp. 798-803, 2014.

[31] Joni, I. M., Nulhakim, L., Vanitha, M. and Panatarani, C., Characteristics of Crystalline Silica $\left(\mathrm{SiO}_{2}\right)$ Particles Prepared by Simple Solution Method using Sodium Silicate $\left(\mathrm{Na}_{2} \mathrm{SiO}_{3}\right)$ Precursor, Journal of Physics: Conference Series, 1080, pp. 1-6, 2018.

[32] Radhika, G., Subadevi, R., Krishnaveni, K., Liu, W. and Sivakumar, M., Synthesis and Electrochemical Performance of PEG- $\mathrm{MnO}_{2}-$ Sulfur Composites Cathode Materials for Lithium-Sulfur Batteries, Journal of Nanoscience and Nanotechnology, 18(1), pp. 127-131, 2018.

[33] Ghosh, J., Glass, C., Meikap, A. K. and Chatterjee, S. K., Microstructural Studies on Variation of Defect Parameters in Zr-Sn Alloys and Their Transition with Interchange of 
Solvent and Solute in Zr-Ti and Ti-Zr Alloy Systems by Modified Rietveld Method and Warren-Averbach Method, Bull Mater Sci., 29(4), pp. 385-390, 2006.

[34] Yesiltepe, D. and Gurmen, S., Production of Nano Zinc Oxide (ZnO) by Hydrothermal Method, UCTEA Chamber of Metallurgical Dan Materials Engineers, pp. 297-299, 2016.

[35] Amelkovich, Y. A., Nazarenko, O. B., Sechin, A. I. and Visakh, P. M., Characterization of Copper Nanopowders after Natural Aging, IOP Conf. Series: Materials Science and Engineering, 81(1), pp. 1-6, 2015.

[36] Mardiansyah, D., Badloe, T., Triyana, K. and Mehmood, M. Q., Effect of Temperature on The
Oxidation of $\mathrm{Cu}$ Nanowires and Development of An Easy to Produce, Oxidation-resistant Transparent Conducting Electrode using a PEDOT: PSS coating, Scientific Reports, 8(10639), pp. 1-9, 2018.

[37] Wahyuningsih, K., Marwoto, P. dan Sulhadi, Kondutivitas dan Transmitansi Film Tipis Zinc Oxide yang Dideposisikan pada Temperatur Ruang, Unnes Physics Journal, 2(1), pp. 37-43, 2013.

[38] Onyia, A. I., Ikeri, H. I. and Nwobodo, A. N., Theoretical Study of The Quantum Confinement Effects on Quantum Dots Using Particle in A Box Model, Journal of Ovonic Research, 14(1), pp. 49-54, 2018. 